\title{
Disposal Analysis of I-129 Bearing Waste Streams at the Intermediate Level Vault
}

by

L. B. Collard

Westinghouse Savannah River Company

Savannah River Site

Aiken, South Carolina 29808

This paper was prepared in connection with work done under the above contract number with the U. S. Department of Energy. By acceptance of this paper, the publisher and/or recipient acknowledges the $U$. $S$. Government's right to retain a nonexclusive, royalty-free license in and to any copyright covering this paper, along with the right to reproduce and to authorize others to reproduce all or part of the copyrighted paper. 
$+2 i \quad i$

WSRC-TR-99-00211

AUGUST 30, 1999

KEYWORDS: PERFORMANCE ASSESSMENT

I-129

INTERMEDIATE LEVEL VAULT

RETENTION: Permanent

DISPOSAL ANALYSIS OF I-129 BEARING WASTE STREAMS AT THE

INTERMEDIATE LEVEL VAULT (U)

Author

Leonard B. Collard

Westinghouse Savannah River Companv

Savannah River Site

Aiken, SC 29808

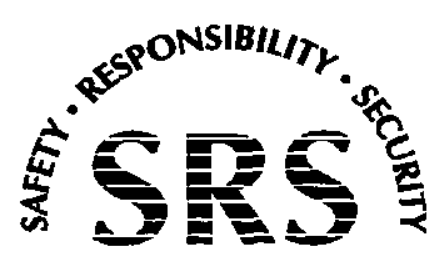




\section{DISCLAIMER}

This report was prepared as an account of work sponsored by an agency of the United States Government. Neither the United States Government nor any agency thereof, nor any of their employees, makes any warranty, express or implied, or assumes any legal liability or responsibility for the accuracy, completeness, or usefulness of any information, apparatus, product, or process disclosed, or represents that its use would not infringe privately owned rights. Reference herein to any specific commercial product, process, or service by trade name, trademark, manufacturer, or otherwise does not necessarily constitute or imply its endorsement, recommendation, or favoring by the United States Government or any agency thereof. The views and opinions of authors expressed herein do not necessarily state or reflect those of the United States Government or any agency thereof.

This report has been reproduced directly from the best available copy.

Available to DOE and DOE contractors from the Office of Scientific and Technical Information, P.O. Box 62, Oak Ridge, TN 37831; prices available from (615) 576-8401.

Available to the public from the National Technical Information Service, U.S. Department of Commerce, 5285 Port Royal Road, Springfield, VA 22161. 


\title{
KEYWORDS: PERFORMANCE ASSESSMENT \\ I-129 \\ INTERMEDIATE LEVEL VAULT
}

\author{
RETENTION: Permanent
}

Author

Leonard B. Collard

Westinghouse Savannah River Companv

Savannah River Site

Aiken, SC 29808

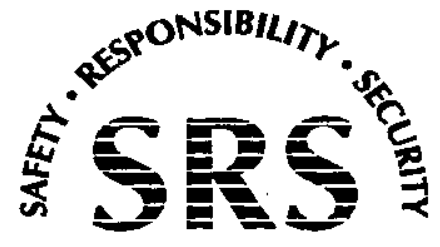


WSRC-TR-99-00211

..$\cdot$

AUGUST 30, 1999

DISPOSAL ANALYSIS OF I-129 BEARING WASTE STREAMS AT THE INTERMEDIATE LEVEL VAULT 


\section{TABLE OF CONTENTS}

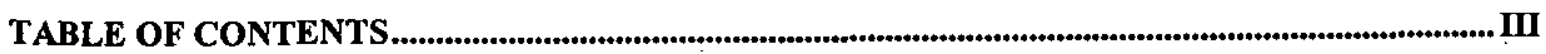

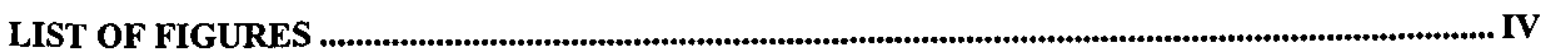

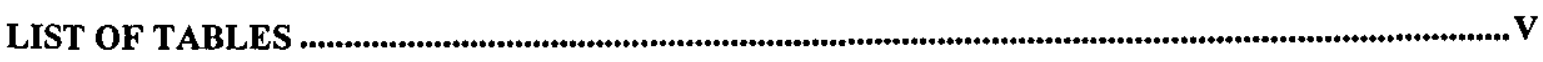

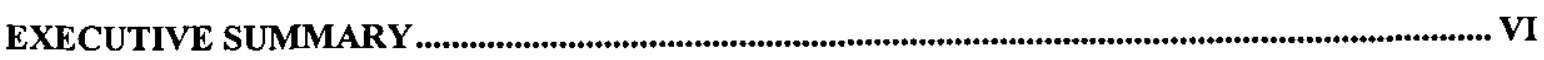

INTRODUCTION

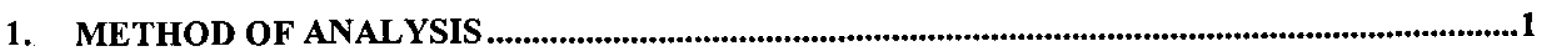

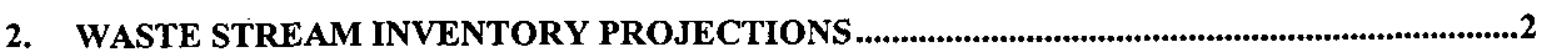

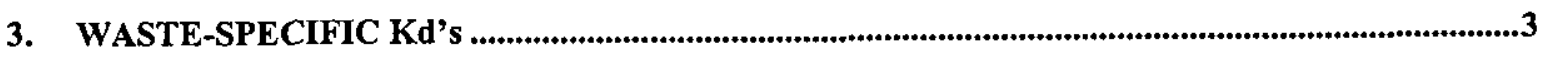

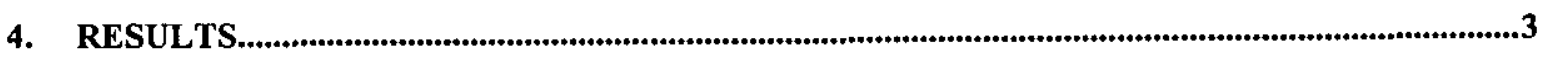

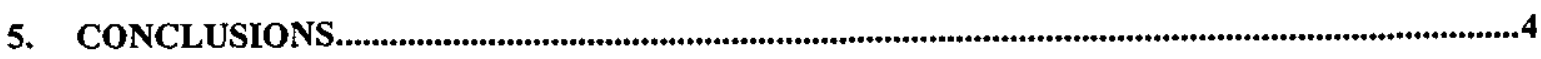

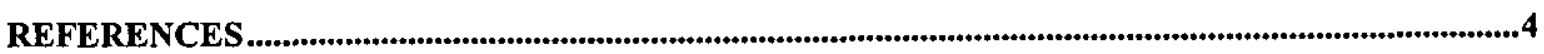




$$
\begin{aligned}
& \because, \quad \because ; t \\
& \therefore \quad \# \quad \because \cdots
\end{aligned}
$$

\section{LIST OF FIGURES}

Figure 1. I-129 Projected Inventories with Generic Limits . .5

Figure 2. I-129 Inventory Limit for Existing Carbon Vessels in ILV over a Range of Waste Kd's......6 Figure 3. I-129 Inventory Limits for 10-Year Projected Activated Carbon Inventory over a Range of

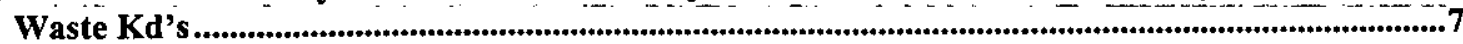

Figure 4. I-129 Inventory Limits for 10 Year Projected GT-73 Inventory over a Range of Waste

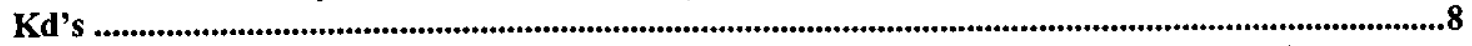

Figure 5. I-129 Inventory Limits for 10-Year Projected Sludge Inventory over a Range of Waste Kd's

Figure 6. I-129 Inventory Limits for 10-Year Projected Dowex 21K Inventory over a Range of Waste Kd's . .10

Figure 7. I-129 Projected Inventories with Generic and Waste-Specific Limits.......................................11 


\section{LIST OF TABLES}

Table i. Waste-Specific I-129 Kd Values.

Table ii. Projected Inventory versus Inventory Limit.....................................................................................vi

Table 1. I-129 Bearing Waste Stream Descriptions.....................................................................................2

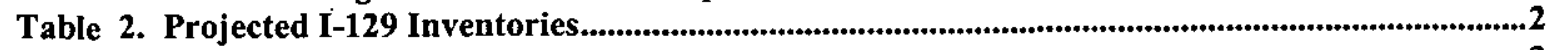

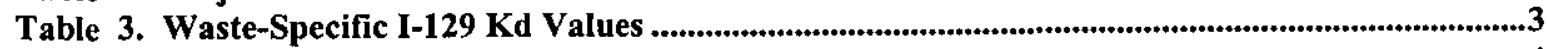

Table 4. Projected Inventory versus Inventory Limit ......................................................................................4 


\section{EXECUTIVE SUMMARY}

This report examines the effects of new waste-specific sorption characteristics reported for I-129 bearing wastes on inventory limits in the Intermediate Level Vault (ILV). The Performance Assessment (PA) (DOE, 1994) limited the I-129 inventory in any vault to 5.3E-4 Ci. A draft PA revision would limit the I129 inventory in any vault to $2.59 \mathrm{E}-4 \mathrm{Ci}$. The ILV currently contains four Activated Carbon vessels with a combined I-129 inventory of $1.92 \mathrm{E}-3 \mathrm{Ci}$ that exceeds both inventory limits.

PA inventory limits are based on computer modeling results that rely on a literature value for the I-129 retention capability ( $\mathrm{Kd}^{1}$ ) of the waste. The PA used a $\mathrm{Kd}$ of $30 \mathrm{ml} / \mathrm{g}$ for I-129 for the ILV waste form, while the PA revision used a $\mathrm{Kd}$ of $2 \mathrm{ml} / \mathrm{g}$. The recently measured $\mathrm{Kd}$ 's for these waste forms are much higher (see Table i), thus increasing the inventory limits. This document describes inventory limits based on the revised PA model using the waste-specific Kd's. Results are compared with inventory projections of waste streams for the next ten years. The ten-year duration was selected because that is the anticipated operational lifetime of the existing ILV.

\begin{tabular}{|l|l|}
\hline \multicolumn{2}{|l|}{ Table i. Waste-Specific I-129 Kd Values } \\
\hline Waste & Kd based on Laboratory Measurements (ml/g) \\
\hline F-Area Dowex 21K & 1800 \\
\hline ETF Activated Carbon & 600 \\
\hline ETF GT-73 & 3100 \\
\hline
\end{tabular}

Each waste stream and the existing ILV inventory of Activated Carbon vessels were modeled independently using their respective Kd's. Models were executed for measured waste-specific Kd's and for a set of hypothetical Kd's ranging from $2 \mathrm{ml} / \mathrm{g}$ (the revised PA value) to $2,000 \mathrm{ml} / \mathrm{g}$. The key modeling result is the I-129 concentration at a hypothetical $100-\mathrm{m}$ downgradient well. This concentration is compared with the Maximum Contaminant Level (MCL) of $0.5 \mathrm{pCi} / \mathrm{L}$ to establish the total inventory limit for the ILV. Waste-specific I-129 inventory limits are plotted against $\mathrm{Kd}$ to show the effect of each $\mathrm{Kd}$.

This modeling indicates new inventory limits based on the draft PA revision. It also introduces new waste categories that are dependent on both the contaminant (i.e., I-129) and the waste form (e.g., Dowex 21K). New modeling results are provided in Table ii. Based on the revised PA and the new waste-specific Kd's, the existing carbon vessels are of minor concem, as is the GT-73. The projected inventory of the carbon vessels essentially matches its inventory limit. The projected inventory of the Dowex $21 \mathrm{~K}$ consumes about one-half of its inventory limit.

\section{Table ii. Projected Inventory versus Inventory Limit}

\begin{tabular}{|l|l|l|r|}
\hline Waste Form & $\begin{array}{l}\text { Inventory Limit } \\
(\mathrm{Ci})\end{array}$ & $\begin{array}{l}\text { Projected Inventory } \\
(\mathrm{Ci})\end{array}$ & $\begin{array}{l}\text { Projected Inventory / } \\
\text { Inventory Limit * }\end{array}$ \\
\hline Existing Carbon Vessels in ILV & $7.13 \mathrm{E}-2$ & $1.92 \mathrm{E}-3$ & 2.7 \\
\hline Activated Carbon Vessels & $7.13 \mathrm{E}-2$ & $7.11 \mathrm{E}-2$ & 99.7 \\
\hline GT-73 & $3.68 \mathrm{E}-1$ & $1.13 \mathrm{E}-3$ & - \\
\hline Sludge & No Kd available & $5.16 \mathrm{E}-4$ & .3 \\
\hline Dowex 21K & $3.33 \mathrm{E}-1$ & $1.78 \mathrm{E}-1$ & \\
\hline
\end{tabular}

Waste streams with waste-specific Kd's must be treated like separate contaminants when conducting the "sum-of-fractions" analysis. The "sum-of-fractions" analysis must be completed to determine the effects of all contaminants in the ILV.

\footnotetext{
'The Kd or distribution coefficient represents the partitioning of waste between solids and liquids. It is defined as the ratio of the concentration in the solids $(\mathrm{Ci} / \mathrm{g})$ to the concentration in the liquid $(\mathrm{Ci} / \mathrm{ml})$.
} 


\section{INTRODUCTION}

Waste streams from water treatment systems, namely the Effluent Treatment Facility (ETF) and the F- and H-Area Water Treatment Units, were discovered to have I-129 levels much higher than expected. In some cases, new characterization data indicated concentrations several orders-of-magnitude greater than Waste Acceptance Criteria (WAC) for the Intermediate Level Vault (ILV). An immediate problem is that Activated Carbon vessels placed in the ILV exceed the Waste Acceptance Criteria (WAC) for I- 129.

Materials in the water treatment systems unexpectedly performed as sorbents for I-129. This behavior was contrary to what was assumed in the Performance Assessment (PA) for the E-Area Vaults (DOE, 1994) which formed the basis for the WAC. To rectify this discrepancy, the sorption property for the waste streams was measured in the laboratory and revised computer models were executed for possible disposal in the ILV. The options of disposing wastes with high I-129 levels in the Low Activity Waste (LAW) vault or in trenches were not addressed in this report.

This Disposal Analysis examined six identified waste streams as follows:

1. ETF Activated Carbon Vessels

2. ETF GT-73 resin

3. ER F-Area Dowex $21 \mathrm{~K}$

4. ER H-Area Dowex $21 \mathrm{~K}$.

5. ER F-Area sludge/filtercake

6. ER H-Area sludge/filtercake.

Zeolites were the most recently discovered waste stream with elevated levels of I-129, but they were not examined in this report.

This Disposal Analysis examined the existing ILV inventory of I-129 and the projected inventory for each identified waste stream for the next ten years. Each waste stream was analyzed separately to determine its waste-specific I-129 inventory limit. $\therefore$,

The Disposal Analysis incorporated laboratory results for I-129 sorption properties with numerical models used in the revision of the E-Area PA of the ILV (DOE, 1998). The sorption property is called the distribution coefficient or $\mathrm{Kd}$; it represents the partitioning of a contaminant between solids and liquids. The waste-specific Kd's are much higher than the values used in the PA revision, resulting in higher inventory limits. The I-129 distribution coefficients (Kd's) were measured for the waste material only; the $\mathrm{Kd}$ used for I-129 migration in the sediments of the vadose zone and aquifer was $0.6 \mathrm{ml} / \mathrm{g}$ from the PA (DOE, 1998).

\section{METHOD OF ANALYSIS}

Modeling results based on unit contaminant inventories were obtained at a hypothetical $100-\mathrm{m}$ downgradient well. Modeling results were scaled by the actual or projected inventories to produce individual waste-stream well concentrations. These concentrations were compared with the Maximum Contaminant Level (MCL) of $0.5 \mathrm{pCi} / \mathrm{L}$ to establish the total inventory limit for all ILV's. Because two ILV's may be operated and their leachate may intermingle, the inventory limit for one ILV is calculated by dividing the total inventory limit by two.

Models were established and initially executed before laboratory results were available; hence, separate models were executed to cover the range of expected laboratory $\mathrm{Kd}$ values. Laboratory $\mathrm{Kd}$ values were used to establish final models. Curves of I-129 inventory limits versus Kd were generated for each waste stream. 


\section{WASTE STREAM INVENTORY PROJECTIONS}

Two waste streams from ETF and four waste streams from ER contain elevated levels of I-129. These waste streams are identified in Table 1. The existing I-129 ILV inventory from these four waste streams consists of four Activated Carbon vessels. Comparing the I-129 inventory in the Activated Carbon vessels in the vault with the inventory in a vessel currently awaiting transport and disposal (the first ETF waste stream in Table 1) indicates that the amount of I-129 in each Activated Carbon vessel can vary significantly. The inventory amount is a function of the concentration in the influent, the efficiency of the medium in removing I-129 from the influent, and the service duration for the medium.

\begin{tabular}{|c|c|c|c|c|c|}
\hline Source & Description & $\begin{array}{l}\text { Annual Volume } \\
\left(\mathrm{ft}^{3}\right)\end{array}$ & $\begin{array}{l}\text { I-129 Conc. } \\
(\mathrm{pCi} / \mathrm{g})\end{array}$ & $\begin{array}{l}\text { Density } \\
\text { (pen) }\end{array}$ & $\begin{array}{l}\text { Annual } \\
\text { Inventory } \\
\text { (Ci) }\end{array}$ \\
\hline Exists & $\begin{array}{l}\text { Current Activated } \\
\text { Carbon Vessel }\end{array}$ & & & & $1.92 \mathrm{E}-3^{2}$ \\
\hline ETF & Activated Carbon Vessel & $1,032(1 \text { vessel })^{3}$ & $301^{4}$ & & $7.11 \mathrm{E}-3^{5}$ \\
\hline ETF & $\begin{array}{l}\text { GT-73 Resin } \\
\text { - OR Hg Col } \\
\text { - IX Hg Col }\end{array}$ & $\begin{array}{l}140^{3} \\
(3 \text { every } 2 \text { yrs }) \\
\text { (1 per year) }\end{array}$ & $\begin{array}{l}36.3^{6} \\
3.71 \mathrm{E}-5(\mathrm{Ci} / \mathrm{Col})^{7} \\
5.77 \mathrm{E}-5(\mathrm{Ci} / \mathrm{Col})^{7}\end{array}$ & $50^{3}$ & $1.13 \mathrm{E}-04$ \\
\hline$\overline{E R}$ & F-Area sludge/filtercake & $\mathrm{NA}^{8}$ & Very low conc. $^{9}$ & $70^{9}$ & 0 \\
\hline ER & H-Area sludge/filtercake & 850 one $y^{9}$ & 19.1 & $70^{9}$ & $5.16 \mathrm{E}-4$ \\
\hline ER & F-Area Dowex $21 \mathrm{~K}$ & $5,400^{9}$ & 119 & $55^{9}$ & $1.78 \mathrm{E}-2$ \\
\hline ER & H-Area Dowex $21 \mathrm{~K}$ & $600^{9}$ & 94 & $55^{9}$ & $\begin{array}{l}\text { Included } \\
\text { with F-Area }\end{array}$ \\
\hline
\end{tabular}

Inventories for F-Area sludge are not included because of its low concentration. The H-Area sludge will only be produced for one year. The projected inventories for $\mathrm{F}$ - and $\mathrm{H}$-Area Dowex $21 \mathrm{~K}$ are combined, because only one sample was provided for measuring $\mathrm{Kd}$. The projected inventories for the next ten years are listed in Table 2. and are plotted in Figure 1. Figure 1 also includes the PA and revised PA limits for generic I-129 wastes (without waste-specific $\mathrm{Kd}$ 's) of $5.3 \mathrm{E}-4 \mathrm{Ci}$ and $2.59 \mathrm{E}-4 \mathrm{Ci}$, respectively.

\section{Table 2. Projected I-129 Inventories}

\begin{tabular}{|l|c|c|r|}
\hline Source & $\begin{array}{l}\text { Annual } \\
\text { Inventory (Ci) }\end{array}$ & $\begin{array}{l}\text { Ten-Year } \\
\text { Inventory (Ci) }\end{array}$ & $\begin{array}{l}\text { Ten-Year } \\
\text { Percentage }\end{array}$ \\
\hline Existing (Activated Carbon) & $1.92 \mathrm{E}-3$ & $1.92 \mathrm{E}-3$ & 0.8 \\
\hline Activated Carbon & $7.11 \mathrm{E}-3$ & $7.11 \mathrm{E}-2$ & 28.1 \\
\hline GT-73 Resin & $1.13 \mathrm{E}-4$ & $1.13 \mathrm{E}-3$ & 0.4 \\
\hline F- and H-Area WTU sludge / filtercake & $5.16 \mathrm{E}-4$ & $5.16 \mathrm{E}-4{ }^{10}$ & 0.2 \\
\hline F- and H-Area Dowex 21K & $1.78 \mathrm{E}-2$ & $1.78 \mathrm{E}-1$ & 70.5 \\
\hline Sum & & $-2.53 \mathrm{E}-1-$ & $-\ldots 0.0$ \\
\hline
\end{tabular}

${ }^{2}$ E-Mail from Sink on June 14, 1999 and personnel communication. $\quad{ }^{3}$

${ }^{3}$ E-Mail from Sink on May 24, 1999 included in E-Mail from Lucha on June 3, 1999.

${ }^{4}$ E-Mail from Walliser on June 7, 1999.

${ }^{5}$ E-Mail from Walliser on June 7, 1999. Although not applied, he recommended increasing the value by a factor of ten. Wiggins recommended using a factor no larger than two in E-Mail on June 28, 1999.

${ }^{6}$ E-Mail from Wailiser on June 28, 1999.

${ }^{7}$ Based on E-Mails from Walliser on June 7, 1999 and June 28, 1999.

${ }^{8}$ Not applicable due to very low concentrations

${ }^{9}$ E-Mail from Lucha on June 3, 1999.

${ }^{10} \mathrm{H}$-Area sludge is only for one year, F-Area sludge has low concentrations - see Table 1. 
The highest inventory source of $0.178 \mathrm{Ci}$ for the Dowex $21 \mathrm{~K}$ represents 70.5 percent of the total projected inventory. The Activated Carbon is the other major contributor to inventory with a projection of $0.0711 \mathrm{Ci}$, representing 28.1 percent of the total. If the Activated Carbon inventory is increased by a factor of two, as recommended by Wiggins, or by a factor of ten, as recommended by Walliser (see Table 1), then its contribution increases to about 44 percent and 89 percent of the total, respectively. The combination of the Existing inventory, the GT-73 Resin, and the sludge account for about one percent of the total projected inventory.

\section{WASTE-SPECIFIC Kd's}

Four samples of different materials bearing I-129 were submitted for Kd testing (Kaplan, et. al., 1999) to represent six waste streams. Because of similarities in operations and materials for the Waste Treatment Units in F-Area and H-Area the sludge/filtercake were considered as the same material. The F-Area and the H-Area Dowex $21 \mathrm{~K}$ were treated similarly.

The sludge/filtercake will not be considered further, because it had too low of an I-129 concentration in the sample for a Kd to be determined. The Activated Carbon had the lowest $\mathrm{Kd}$ of $600 \mathrm{ml} / \mathrm{g}$, while the GT-73 had the highest value of $3,100 \mathrm{ml} / \mathrm{g}$. These values are significantly higher than literature values of $30 \mathrm{ml} / \mathrm{g}$ and $2 \mathrm{ml} / \mathrm{g}$ used in the PA and its revision for cement-based wastes.

\begin{tabular}{|l|l|}
\hline Table 3. Waste-Specific I-129 Kd Values \\
\hline Waste & $\begin{array}{l}\text { Kd based on Laboratory Measurements } \\
(\mathrm{m} / \mathrm{g})\end{array}$ \\
\hline ETF Activated Carbon & 600 \\
\hline ETF GT-73 & 3100 \\
\hline F-Area Dowex 21K & 1800 \\
\hline
\end{tabular}

\section{RESULTS}

Modeling was conducted over a range of waste $\mathrm{Kd}$ values from $2 \mathrm{ml} / \mathrm{g}$, the value from the draft PA revision, to $2,000 \mathrm{ml} / \mathrm{g}$. The Kd range was extended to include the GT-73 waste-specific Kd of $3,100 \mathrm{ml} / \mathrm{g}$. The model results were converted to inventory limits. The vault inventory limits for each waste stream are plotted against the input Kd's in Figures 2 to 6 as follows:

- Figure 2 Existing ILV inventory of Activated Carbon

- Figure 3 Projected Activated Carbon Excluding Existing Inventory

- Figure 4 GT-73

- Figure 5 Dowex $21 \mathrm{~K}$

The results for waste-specific Kd's (see Table 3) based on laboratory measurements are plotted in those figures as a shaded circle. The results for the waste $\mathrm{Kd}$ from the PA revision $(2 \mathrm{ml} / \mathrm{g})$ are highlighted as a shaded diamond in the plot.

Table 4 provides a comparison of each waste form's projected inventory with inventory limits generated from modeling results. The existing inventory of activated carbon vessels in the ILV is only about three percent of the proposed inventory limit. The projected Activated Carbon Vessel inventory almost exactly matches its proposed inventory limit. The projected GT-73 inventory is less than one percent of its proposed inventory limit. The projected Dowex $21 \mathrm{~K}$ inventory is about one-half its projected inventory limit. This information is graphed in Figure 7 with the PA limits for generic I-129 waste to show the advantages of having waste-specific Kd's. 


\begin{tabular}{|c|c|c|c|}
\hline Waste Form & $\begin{array}{l}\text { Indicated Inventory } \\
\text { Limit } \\
\text { (Ci) }\end{array}$ & $\begin{array}{l}\text { Projected Inventory } \\
\text { (Ci) }\end{array}$ & $\begin{array}{l}\text { Projected Inventory / } \\
\text { Inventory Limit * } \\
100 \%\end{array}$ \\
\hline Existing Carbon Vessels in ILV & $7.13 \mathrm{E}-2$ & $1.92 \mathrm{E}-3$ & 2.7 \\
\hline Activated Carbon Vessels & $7.13 \mathrm{E}-2$ & $7.11 \mathrm{E}-2$ & 99.7 \\
\hline GT-73 & $3.68 \mathrm{E}-1$ & $1.13 \mathrm{E}-3$ & .3 \\
\hline Dowex $21 \mathrm{~K}$ & $3.33 \mathrm{E}-1$ & $1.78 \mathrm{E}-1$ & 53.5 \\
\hline
\end{tabular}

\section{CONCLUSIONS}

The activated carbon vessels pose the greatest challenge, because the projected inventory is the closest to the inventory limit. The Dowex $21 \mathrm{~K}$ is important because its projected inventory is about one-half the inventory limit. The existing carbon vessels and the GT-73 are much less significant.

The individual waste-specific results provide information for the selection of an optimum disposal strategy. Based on the volumes of each waste stream and the costs of disposal at different locations, it will be possible to minimize disposal costs. For example, I-129 bearing wastes may be disposed in the LAW vault or off-site.

Waste-specific Kd's must be determined for waste stream materials that significantly sorb I-129 if WAC revisions are desired. The $\mathrm{H}$-Area sludge/filtercake and some zeolites have been identified as belonging to this category of significant I-129 sorbents. As stated in the laboratory report, the use of "getter" materials may prove beneficial for seemingly intractable problem wastes, such as the activated carbon.

\section{REFERENCES}

DOE (U.S. Department of Energy), 1994, Draft Radiological Performance Assessment for the E-Area LowLevel Waste Facility, WSRC-RP-94-218, Savannah River Operations Office, Aiken, South Carolina, April 15, 1994.

DOE (U.S. Department of Energy), 1998, Draft Radiological Performance Assessment for the E-Area LowLevel Waste Facility, WSRC-RP-94-218, Savannah River Operations Office, Aiken, South Carolina, September 23, 1998.

Kaplan, D.I., S.M. Serkiz, and N.C. Bell, 1999, I-129 Desorption from SRS Water Treatment Media From the Effluent Treatment Facility and the F-Area Groundwater Treatment Facility, WSRC-TR-99-270, Savannah River Technology Center, Westinghouse Savannah River Company, Aiken, SC, August 24, 1999.

Lucha, 1999. E-Mail on June 3, 1999.

Walliser, 1999a. E-Mail on June 7, 1999.

Sink, 1999. E-Mail on June 14, 1999.

Wiggins, 1999. E-Mail on June 28, 1999.

Walliser, 1999b. E-Mail on June 28, 1999. 

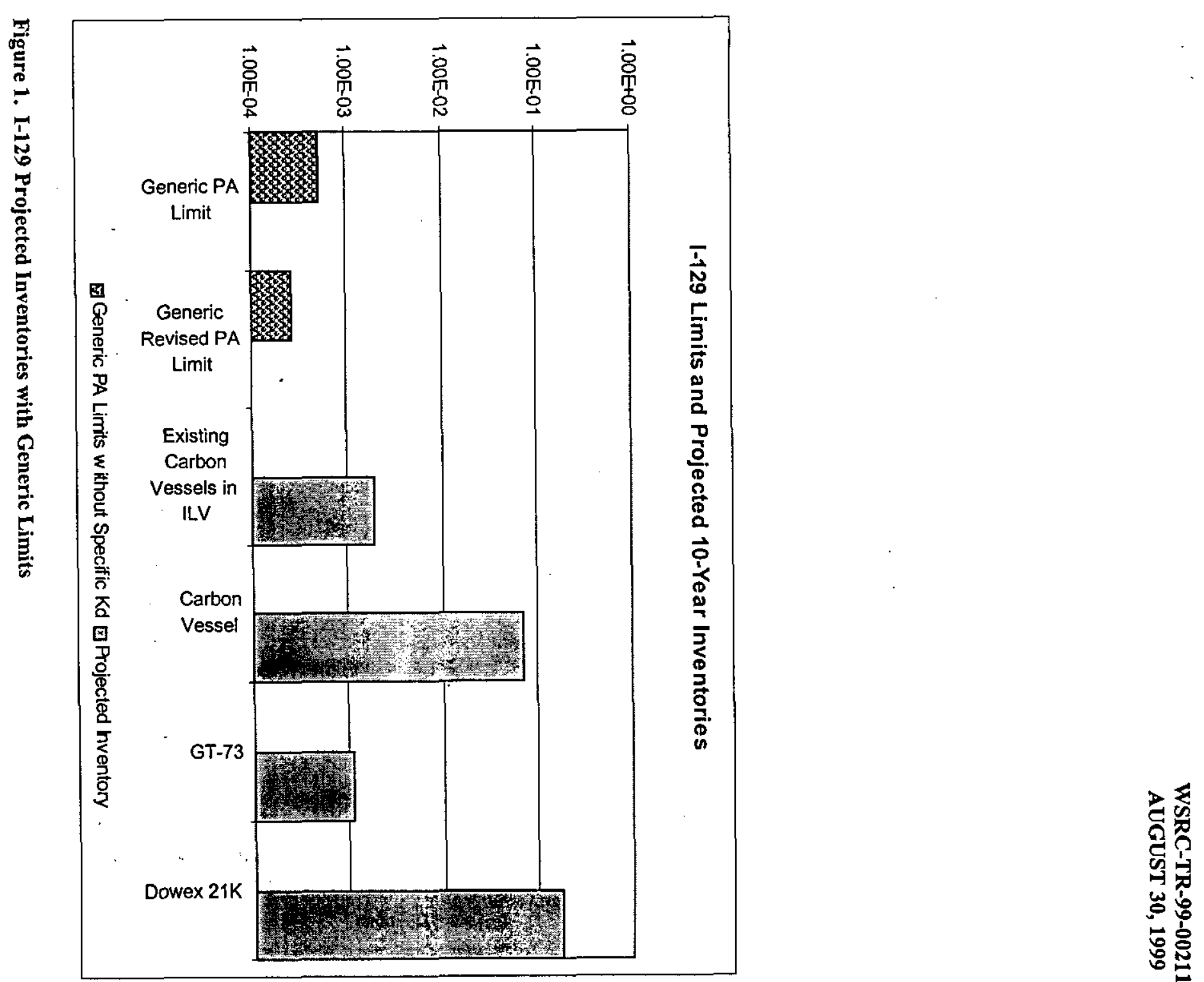


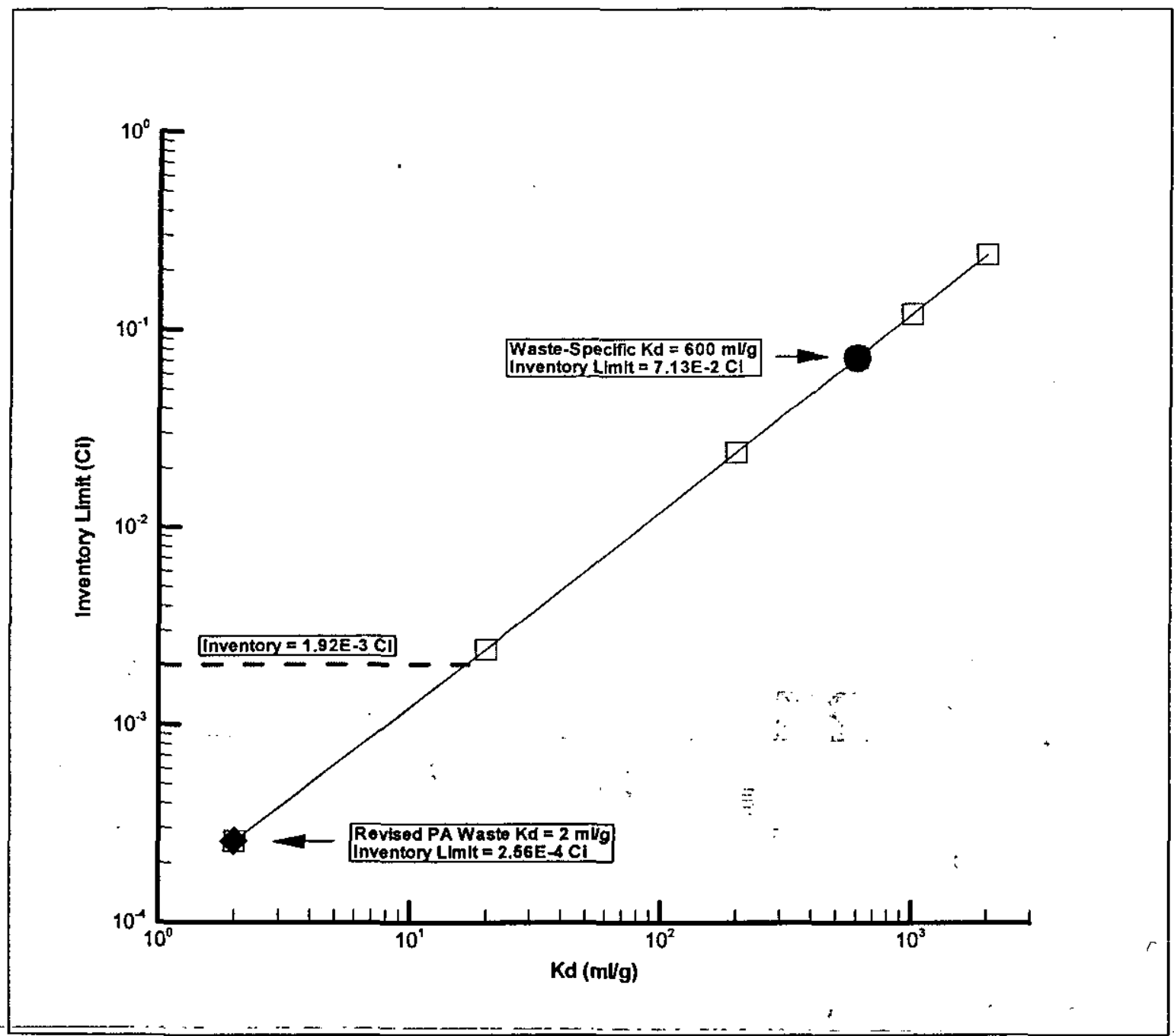

Figure 2. I-129 Inventory Limit for Existing Carbon Vessels in ILV over a Range of Waste Kd's 


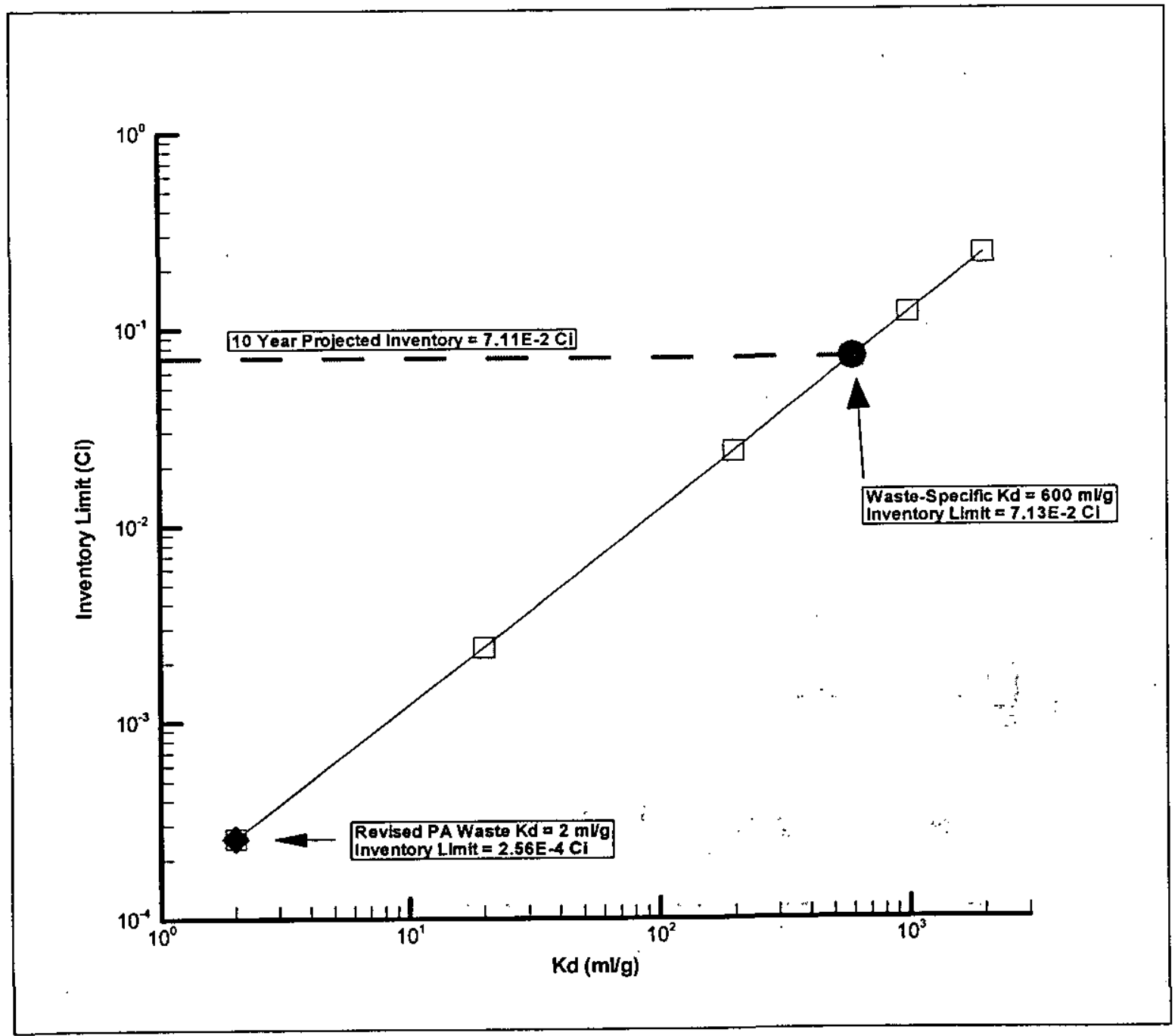

Figure 3. I-129 Inventory Limits for 10-Year Projected Activated Carbon Inventory over a Range of Waste Kd's 


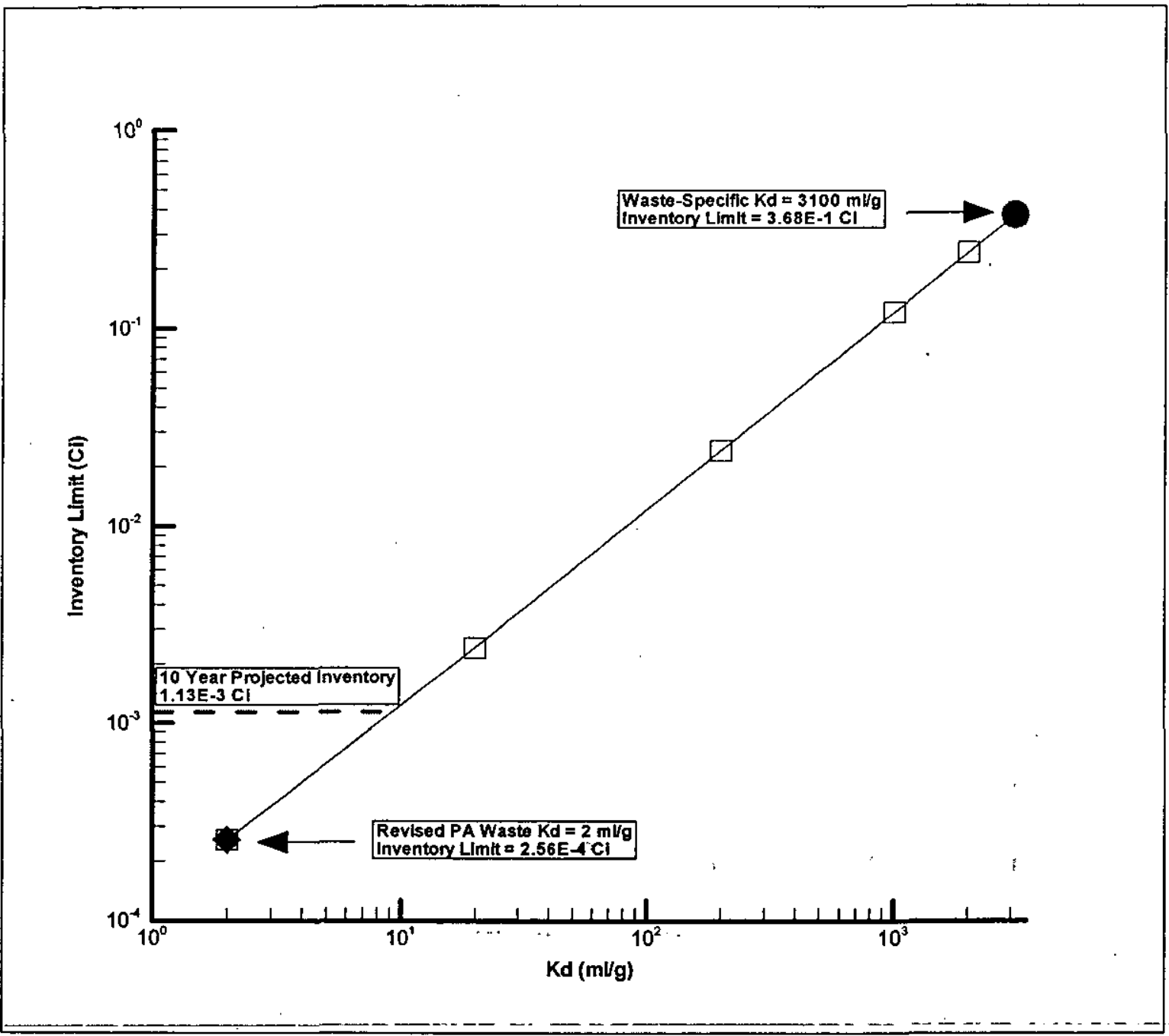

Figure 4. I-129 Inventory Limits for 10 Year Projected GT-73 Inventory over a Range of Waste Kd's 


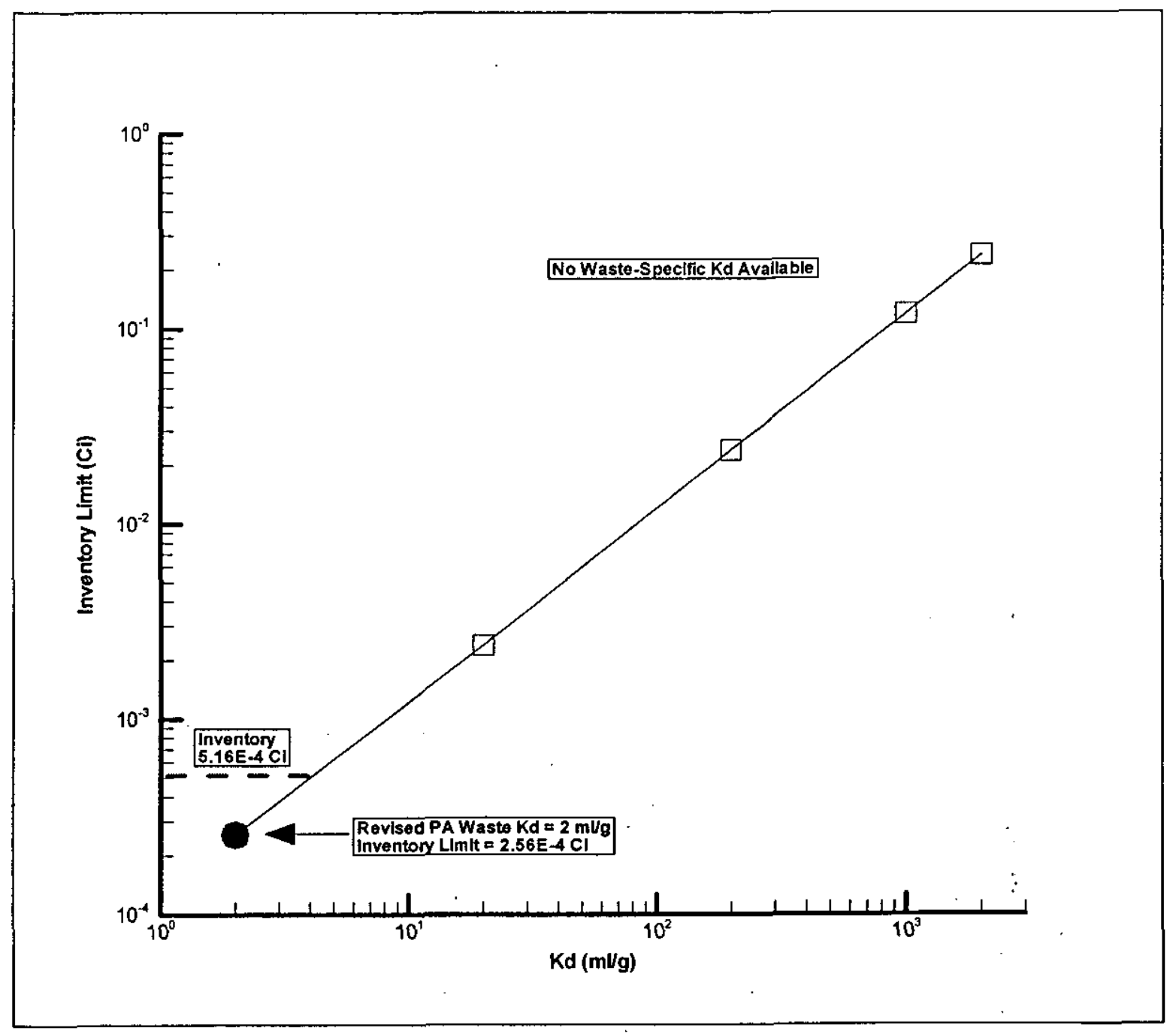

Figure 5. I-129 Inventory Limits for 10-Year Projected Sludge Inventory over a Range of Waste Kd's 


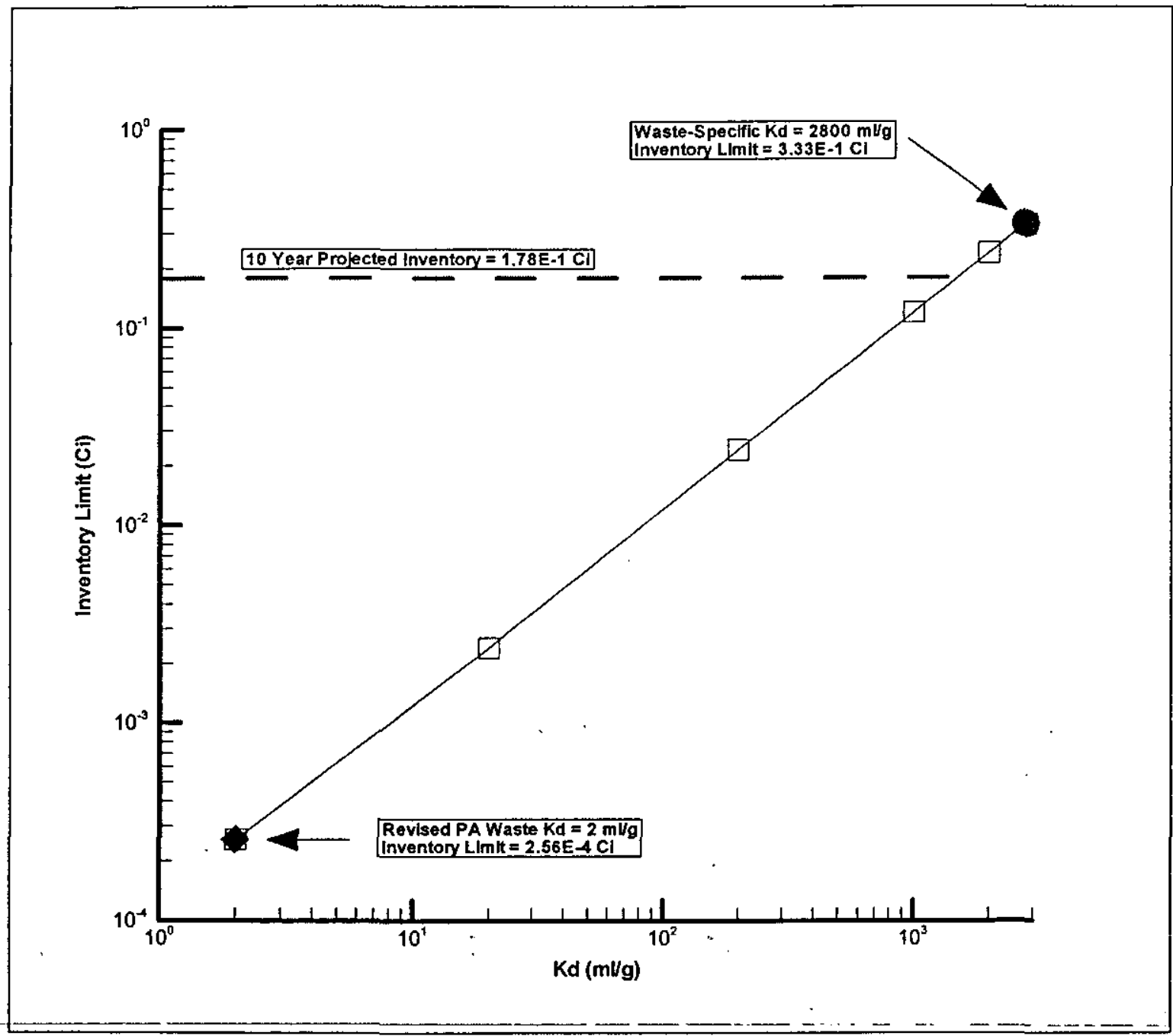

Figure 6. I-129 Inventory Limits for 10-Year Projected Dowex 21K Inventory over a Range of Waste Kd's 


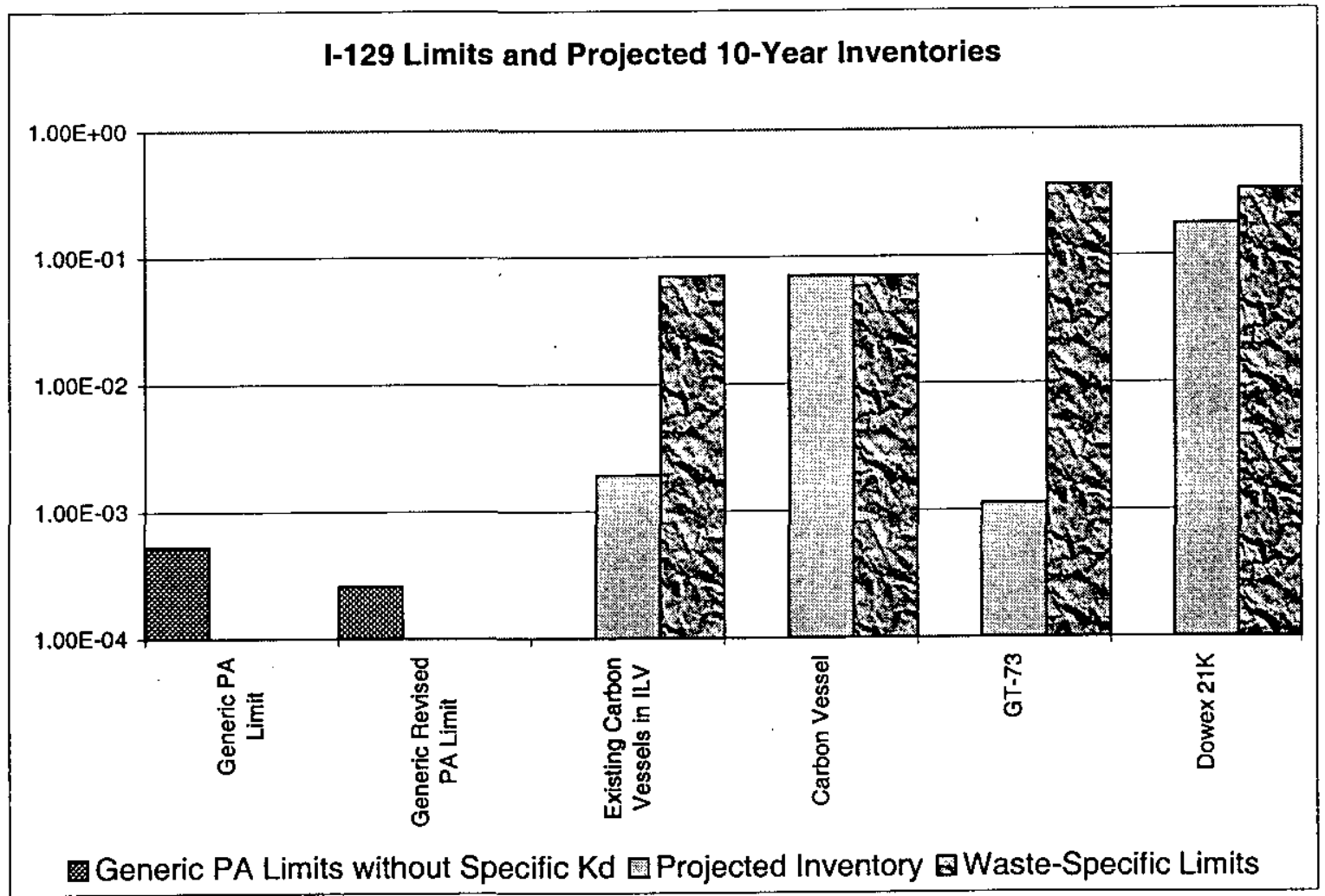

Figure 7. I-129 Projected Inventories with Generic and Waste-Specific Limits 